\title{
Survey for Little Leaf of Brinjal Disease (Candidatus phytoplasmatrifolii) Incidence in Northern Karnataka, India
}

\author{
Rathnamma* and M.S. Patil \\ Department of Plant Pathology, University of Agricultural Sciences, \\ Krishinagar, UAS, Dharwad-580005, Karnataka, India \\ *Corresponding author
}

\section{A B S T R A C T}

\begin{tabular}{l} 
Ke y w or d s \\
$\begin{array}{l}\text { Candidatus } \\
\text { phytoplasmatrifolii, } \\
\text { Brinjal, Little leaf. }\end{array}$ \\
Article Info \\
\hline $\begin{array}{l}\text { Accepted: } \\
\text { 12 September } 2017 \\
\text { Available Online: } \\
10 \text { November } 2017\end{array}$ \\
\hline
\end{tabular}

Little leaf disease caused by phytoplasma (Candidatus phytoplasmatrifolii) is one of the important diseases in Brinjal. In recent years incidence of little leaf disease is increasing in Karnataka. The roving survey was undertaken to know the incidence of little leaf phytoplasma disease of brinjal in different parts of northern Karnataka viz., Dharwad, Belgaum and Haveri districts during kharif, 2013. It was evident that the disease was severe in all the districts during kharif, 2013 and the average disease incidence recorded from 20.55 to 35.44 per cent in northern Karnataka. The maximum disease incidence of 35.44 per cent was recorded at Dharwad district followed by Belgaum district 32.48 per cent and minimum disease incidence was noticed in 20.55 per cent in Haveri district.

\section{Introduction}

The brinjal or eggplant (Solanum melongena L.) belongs to the family Solanaceae. Brinjal is the most common, popular and widely grown vegetable crop of both tropics and subtropics of the world. Brinjal is a selfpollinated and annual herbaceous plant. It is being grown extensively in India, Bangladesh, Pakistan, China, Philippines, France, Italy and United States. Vavilov (1931) reported that India is the centre of origin. It is highly productive and finds its place as the poor man's vegetable (Som and Maity, 2002).

It is grown in almost all parts of India, except in higher altitudes throughout the year.
Brinjal is affected by several diseases of which little leaf causing phytoplasma is one of the most important disease causing considerable economic losses (Mitra, 1993). The infected plants are characterized by severe stunting, shortened internodes, proliferation of shoots, and reduction in leaf size and phyllody of flowers. Brinjal little leaf disease was first reported in the central farm, Coimbatore by Thomas and Krishnaswamy (1939) and several biological aspects of the disease have been described (Varma et al., 1969; Mitra, 1993). The insect vector, Hishimonus phycitis Distant was reported by (Bindra and Singh, 1969). 
Plants infected with phytoplasmas exhibit symptoms suggesting a profound disturbance in the normal balance of growth regulators, leading to virescence/ phyllody i.e., development of green leaf-like structures instead of flowers, sterility of flowers, proliferation of axillary buds resulting in "witches broom" symptoms, abnormal internode elongation and generalized stunting (Bertaccini, 2007). Phytoplasmas are transmitted by insects belonging to the families' viz., Cicadellidae, Cixidae, Psyllidae, Delphacidae and Derbidae (Weintraub and Beanland, 2006).

\section{Materials and Methods}

The roving survey was conducted during kharif/summer season 2013 to know the per cent disease incidence of little leaf of brinjal and prevalence of leafhopper populations in three major brinjal growing areas of Karnataka i.e. Dharwad, Belgaum and Haveri districts. In each village five fields were selected and the percent of disease incidence was assessed by recording the number of plants showing disease symptoms and the total number of plants examined by using the formula.

Number of diseased plants Disease incidence $(\%)=\longrightarrow 100$ Total number of plants examined

\section{Results and Discussion}

The roving surveys were undertaken to know the incidence of little leaf phytoplasma disease of brinjal in different parts of Northern Karnataka viz., Dharwad, Belgaum and Haveri districts during kharif, 2013 when the crop was in flowering stage and fruiting stage. During survey brinjal plants showing typical symptoms of reduction in the size of the leaves, leaf curling or cupping, Yellowing, reduction in the petiole and the lamina, flower is converted into leaf like structure, Malformation of brinjal fruits were observed (Fig. 1).

From the survey it is revealed that the disease was severe in all the districts during kharif, 2013 and disease incidence ranged from 2 to 95 per cent in different parts of the districts surveyed. The highest incidence $(95 \%)$ of Little leaf phytoplasma disease was noticed in fields of Garaga village in Dharwad district, whereas least $(2 \%)$ incidence of the disease was recorded at Hedigonda village of district Haveri.

\section{Village wise incidence}

The incidence in Dharwad district ranged from 10 to 95 per cent. The maximum incidence of the disease 95 per cent was recorded in Garag village of Dharwad taluk at flowering stage, followed by 70 and 60 per cent incidence in Kundagol taluk and Hebsur village of Hubli taluk respectively. However, the minimum incidence of 10 percent was recorded in UAS campus of Dharwad taluk. The incidence in Belgaum district ranged from 7 to 90 per cent. The maximum incidence of the disease 90 per cent was recorded in Muragod village of Bailahongal taluk at fruiting stage, followed by 65 and 61.4 per cent incidence in Belavadagi village of Bailahongal taluk and Yamakanamaradi village of Hukkeri taluk respectively. However, the minimum incidence of 7 per cent was recorded in Sankeshwar village of Hukkeri taluk. The incidence in Haveri district ranged from 2 to 44.5 per cent. The maximum incidence of the disease 44.5 per cent was recorded in Akkialur village of Hanagal taluk at fruiting stage, followed by 36.7 and 34.7 per cent incidence in Ranebennur and Byadagi respectively. However, the minimum incidence of 2 per cent was recorded in Hedigonda village of Byadagi taluk (Table 1). 
Table.1 Incidence of brinjal little leaf in various villages in northern Karnataka during kharif 2013

\begin{tabular}{|c|c|c|}
\hline \multicolumn{3}{|c|}{ Dharwad District } \\
\hline Taluk & Villeges name & Incidence $(\%)$ \\
\hline \multirow{9}{*}{ Dharwad } & UAS, Campus & 10.00 \\
\hline & Narendra & 16.00 \\
\hline & Garaga & 95.00 \\
\hline & Govanakoppa & 37.50 \\
\hline & Somapura & 15.00 \\
\hline & Sulla & 25.00 \\
\hline & Byahatti & 12.00 \\
\hline & Shivalli & 45.00 \\
\hline & Tadakoda & 35.00 \\
\hline \multirow[t]{4}{*}{ Hubli } & Bhadrapura & 38.00 \\
\hline & Annigere & 30.00 \\
\hline & Hebsur & 60.00 \\
\hline & Siraguppi & 36.00 \\
\hline \multirow[t]{5}{*}{ Kundagol } & Kundagol & 70.00 \\
\hline & Saunsi & 15.00 \\
\hline & Gudigeri & 25.00 \\
\hline & Devanuru & 30.00 \\
\hline & Kambadhalli & 45.00 \\
\hline \multirow[t]{5}{*}{ Navalagund } & Alagavadi & 20.00 \\
\hline & Amaragol & 5.00 \\
\hline & Belavatagi & 36.4 \\
\hline & Karalawada & 22.5 \\
\hline & Karalgund & 50.00 \\
\hline \multirow[t]{4}{*}{ Kalagatagi } & Hulikoppa & 32.00 \\
\hline & Hirenalli & 30.00 \\
\hline & Devikoppa & 42.00 \\
\hline & Dummavada & 57.50 \\
\hline \multicolumn{3}{|c|}{ Belgaum District } \\
\hline Taluk & Villages name & Incidence (\%) \\
\hline \multirow[t]{5}{*}{ Savadatti } & Hirehulligere & 40.00 \\
\hline & Kabbenuru & 18.00 \\
\hline & Karikatte & 24.8 \\
\hline & Yadalli & 14 \\
\hline & Inchal & 55.4 \\
\hline \multirow[t]{5}{*}{ Bailahongal } & Muragoda & 90.00 \\
\hline & Belavadi & 65.00 \\
\hline & Kenganura & 44.2 \\
\hline & Nesargi & 25.00 \\
\hline & Madanabavi & 20.00 \\
\hline \multirow[t]{5}{*}{ Gokak } & Tukkanatti & 40.00 \\
\hline & Kallolli & 11.00 \\
\hline & Kolvi & 20.00 \\
\hline & Gilihosaru & 34.6 \\
\hline & Ankalagi & 12.00 \\
\hline \multirow[t]{3}{*}{ Chikodi } & Nagarmunoli & 15.00 \\
\hline & Navalihal & 14.00 \\
\hline & Shamanewadi & 37.4 \\
\hline Hukkeri & Borgal & 44.6 \\
\hline
\end{tabular}




\begin{tabular}{|c|c|c|}
\hline & Yamakanamaradi & 61.4 \\
\hline & Sankeshwar & 7.00 \\
\hline \multicolumn{3}{|c|}{ Haveri District } \\
\hline Taluk & Villages name & Incidence (\%) \\
\hline \multirow[t]{4}{*}{ Haveri } & Devihosur & 8.0 \\
\hline & Nelogalla & 10.3 \\
\hline & Devagiri & 26.5 \\
\hline & Haveri & 25.00 \\
\hline \multirow[t]{4}{*}{ Ranebennur } & Ranebennur & 36.7 \\
\hline & Halageri & 23.00 \\
\hline & Hanumanamatti & 9.00 \\
\hline & Kakola & 15 \\
\hline \multirow[t]{4}{*}{ Byadagi } & Byadagi & 34.7 \\
\hline & Hedigonda & 2 \\
\hline & Sidenur & 13.0 \\
\hline & Kanamadi & 6.4 \\
\hline \multirow[t]{2}{*}{ Hirekerur } & Hirekerur & 15.00 \\
\hline & Hamsabhavi & 23.00 \\
\hline \multirow[t]{3}{*}{ Hanagal } & Akkihalur & 44.5 \\
\hline & Negavanagi & 24.8 \\
\hline & Tilavalli & 25.00 \\
\hline
\end{tabular}

Table.2 Average incidence of brinjal little leaf in various taluks of northern Karnataka during kharif 2013

\begin{tabular}{|c|c|c|c|}
\hline Taluk & Number of villages surveyed & Incidence range & Incidence average \\
\hline \multicolumn{4}{|c|}{ Dharwad district } \\
\hline Dharwad & 9 & $10-95$ & 32.20 \\
\hline Hubli & 4 & $30-60$ & 41.00 \\
\hline Kundagol & 5 & $15-70$ & 37.00 \\
\hline Navalagund & 5 & $5-50$ & 26.70 \\
\hline Kalagatagi & 4 & $30-57$ & 40.30 \\
\hline \multicolumn{2}{|l|}{ Average } & \multicolumn{2}{|l|}{35.44} \\
\hline \multicolumn{4}{|c|}{ Belgaum district } \\
\hline Savadatti & 5 & $14-55.4$ & 30.40 \\
\hline Bailahongal & 5 & $20-90$ & 48.80 \\
\hline Gokak & 5 & $11-40$ & 23.50 \\
\hline Chikodi & 3 & $14-37.4$ & 22.10 \\
\hline Hukkeri & 3 & $7-44.6$ & 37.60 \\
\hline \multicolumn{2}{|l|}{ Average } & \multicolumn{2}{|c|}{32.48} \\
\hline \multicolumn{4}{|c|}{ Haveri district } \\
\hline Haveri & 4 & $8-26.5$ & 17.45 \\
\hline Ranebennur & 4 & $9-36.7$ & 20.90 \\
\hline Byadagi & 4 & $2-34.7$ & 14.00 \\
\hline Hirekerur & 2 & $15-23$ & 19.00 \\
\hline Hanagal & 3 & $24.8-44.5$ & 31.40 \\
\hline \multicolumn{2}{|l|}{ Average } & \multicolumn{2}{|c|}{20.55} \\
\hline
\end{tabular}


Table.3 Little leaf disease of brinja incidence - District wise

\begin{tabular}{|c|c|c|c|c|c|}
\hline Sl. No. & Di District & N Number of fields & \multicolumn{3}{|c|}{ Pe Percent Disease Incidence } \\
\cline { 4 - 6 } & & & minimum & $\begin{array}{c}\text { M } \\
\text { maximum }\end{array}$ & $\begin{array}{c}\text { A } \\
\text { Average }\end{array}$ \\
\hline 111 & Dharwad & 135 & 5 & 95 & 50 \\
\hline 2 & Belgaum & 105 & 7 & 90 & 48.5 \\
\hline 3 & Haveri & 85 & 2 & 44.5 & 23.25 \\
\hline
\end{tabular}

Fig.1 Brinjal little leaf disease symptoms



\section{Taluk wise incidence}

The incidence in Dharwad district taluks, the maximum incidence of 41 per cent was recorded in Hubli taluk followed by 40.3 and 37 per cent in Kalagatagi and Kundagol taluk respectively. However, the minimum incidence of 26.7 per cent was recorded in Navalagund taluk. The incidence in Belgaum district taluks, the maximum incidence of 48 per cent was recorded in Bailahongal taluk followed by 37.6 and 30.4 per cent in Hukkeri and Savadatti taluk respectively. However, the minimum incidence of 22.1 per cent was recorded in Chikodi taluk. The incidence in Haveri district taluks, the maximum incidence of 31.4 per cent was recorded in Hanagal taluk followed by 20.9 and 17.45 per cent in Ranebennur and Haveritaluk respectively. However, the minimum incidence of 14 per cent was recorded in Byadagi taluk (Table 2).

\section{District wise incidence}

On an average, the maximum disease incidence of 35.44 per cent was recorded at Dharwad district followed by Belgaum district 32.48 per cent and minimum disease incidence was noticed in 20.55 per cent in Haveri district (Table 3).

The roving survey during kharif2013 was undertaken to know the incidence of little leaf phytoplasma disease of brinjal (Solanum melongena L.) in northern Karnataka. The results revealed that the per cent disease incidence varied from place to place.

The disease was present in all the parts of the Dharwad, Belgaum, and Haveri districts in northern Karnataka. The average disease incidence ranged from 20.55 to 35.44 per cent. 


\section{References}

Bertaccini, A., 2007, Phytoplasmas: diversity, taxonomy, and epidemiology. Frontieres in Biosci., 12: 673-689.

Bindra, O. S. and Singh, B., 1969, Biology and bionomics of Hishimonusphycitis (Distant), a jassid vector of little leaf disease of brinjal (Solanum melongena L.). Indian J. Agric. Sci., 39: 912-919.

Mitra, D. K., 1993, little leaf, a serious disease of eggplant (Solanum melongena). In: Management of plant diseases caused by fastidious prokaryotes, edited by Raychaudhuri, S. P. and Teakle, D. S., India, New Delhi: Associated Publishing Co., pp. 73-78.

Som, M., G. and Maity, J. K., 2002, Brinjal vegetable crops, $3^{\text {rd }}$ revised edition, Ed. Bose, T. K., Kabir, J., Maity, T. K., Parthasarthy, V. A. and Som, M. G.,
Nayaprakash publishers, Kolkatta. 1: 265-344.

Thomas, K. M. and Krishnaswami, C. S., 1939, "Little-leaf" - a transmissible disease of brinjal. Proc. Indian Acad. Sci., 10: 201-212.

Varma, A., Raychaudhuri, S. P., Chenulu, V. V., Singh, S., Ghosh, S. K. and Prakash, N., 1969, Yellows Type of Diseases in India: Eggplant little leaf. Division of Mycology and Plant Pathology, Indian Agricultural Research Institute, New Delhi.

Vavilov, N. I., 1931, The role of central Asia in the origin of cultivated plants. Bull. Appl. Bot. Genet. Pl. Breed, 26(3): 3-44. Weintraub, P. G. and Beanland, L., 2006, Insect vectors of phytoplasmas. Ann. Rev. Entomol., 51: 91-111.

\section{How to cite this article:}

Rathnamma and Patil, M.S. 2017. Survey for Little Leaf of Brinjal Disease (Candidatus Phytoplasmatrifolii) Incidence in Northern Karnataka. Int.J.Curr.Microbiol.App.Sci. 6(11): 1248-1253. doi: https://doi.org/10.20546/ijcmas.2017.611.148 